\title{
DE ESTRELLAS Y BARCOS
}

Mariana Bernárdez*

¿Un poema? ¿Diferentes poemas? Creo que un poema. Decide lector. ${ }^{1}$

\section{Escribo Xirau y sé que siempre me} acompañará el asombro que me produjo el pasaje sobre la muerte del Minotauro como advenimiento de la razón, en la Introducción a la historia de la filosofia. Digo Xirau para contarme este pasar de mis años leyéndolo y dejándome cautivar por ese juego desplegado en su ensayo, por ese ejercicio discursivo que arrastra hacia la complicidad inevitable, eje sobre el que la reflexión se arriesga en su posibilidad exploratoria y donde el discurrir se concentra en la recurrencia para lograr una vía en la que filosofía y poesía son registro del tiempo vivido.

Deletreo Xirau y cuando lo hago pienso su figura acompañada por la mañana atravesando las ventanas de su estudio, sonriéndose ante un mar adormilado por el vaivén de barcas, aquietándose ante la urdimbre de las jacarandas y descifrando las aporías de Zenón frente a unas naranjas. Conocí a algunos que tenían como regalo preciado el recuerdo de sus clases, ninguno dejaba atrás la impronta de ese hablar tan suyo que a manera de rumor aún se estremece tras la estela de la claridad:

Es famosa la dicción oscura con la que Ramón dice cosas luminosas. Las palabras más socorridas entre sus alumnos eran: ¿perdón?, ¿cómo?,

* Ensayista.

${ }^{1}$ Ramón Xirau, "Epígrafe al poema Gradas”, Poemes. Poemas, 1990, México, Ediciones Toledo, trad. Andrés Sánchez Robayna, p. 23. 
¿qué dijo? Su método, pues, era también mayéutico, sólo que invertido: los alumnos tenían que alumbrar las palabras en el maestro. Una tarde, en que el coro de cómos y qués se había multiplicado más de lo normal, Xirau exclamó de pronto, con nitidez meridiana: “ $¡ Y$ no crean que no puedo hablar claro!", volviendo en seguida a su tono crepuscular: "Lo que pasa es que no quiero."2

Hombre puente lo llamó Paz en su momento: “A semejanza de esas construcciones prodigiosas de la ingeniería moderna, sus ensayos son un puente que une no a dos, sino a varias orillas. [...] puente entre sus dos vocaciones más ciertas y profundas, la poesía y la filosofía."3 Hombre puente cuya charla vívida señala una diversidad de pensadores y sobrecoge la agudeza con la cual Aristóteles, Vico, Mallarmé, Rimbaud, Bergson, Kierkegaard, Borges, Plotino, San Juan de la Cruz encuentran cabida en la observación que hace en voz alta sobre la nervadura de una hoja y los colores que fulgen al caer la tarde.

Detrás de un mismo semblante, Xirau es uno en muchos otros: el maestro que inauguró en la Facultad de Filosofía y Letras el Seminario de Filosofía y Poesía en 1966; el pensador de expresión equitativa y amorosa cuyos escritos fueron detonantes para la apreciación de la literatura hispanoamericana y la divulgación de las nuevas discusiones en torno a la filosofía; el poeta que conservó el catalán como lengua materna para ensoñarse; el traductor de Bergson, Nagel y Newman, Denise de Rougemont, por mencionar algunos; y el editor por más de 20 años de la revista Diálogos, foro para una pluralidad de autores y textos y cala de una época significativa en el quehacer cultural y la conformación del pensamiento del siglo XX en México. Subyace en estas trayectorias un cumplimiento de la palabra, por su luminosidad y nitidez, y por su recogimiento y persistencia.

${ }^{2}$ Luis Ignacio Helguera, "Imagen crepuscular de Ramón Xirau”, en Poesía, ensayo y crítica en la vida de Ramón Xirau, 2000, México, El Ermitaño-Minimalia, CONACULTA \& FONCA, p. 288.

${ }^{3}$ Octavio Paz, "Contestación al discurso de ingreso de Ramón Xirau a El Colegio Nacional”, en Saludos y homenajes. Palabras para miembros de El Colegio Nacional, 1999, México, El Colegio Nacional, p. 83-4. 
Ramón Xirau incursiona lo mismo en la poesía que en la abstracción filosófica, o en la crítica literaria. Y en tan diversos géneros suele demostrar que la inteligencia se aviene con la apreciación estética, y que el conocimiento no riñe con la imaginación. [...] El poeta, el filósofo y el crítico se funden en el hombre de letras, en el intelectual que da fe de su persona, mediante la interpretación del espacio y el tiempo en que su vida alienta la esperanza. ${ }^{4}$

Frente a la atrocidad de la guerra, no sorprende que la obra de Xirau se circunscriba al pulso de su época y comparta, con la generación del exilio español, ciertas preocupaciones que se reflejarán en su trabajo. Ante el resquebrajamiento de una filosofía de sistema, el cuestionamiento severo de la angustia como condición inevitable del ser y el golpe infringido en la raíz del pensamiento por la espiral violentísima de la impiedad, responde particularmente con una filosofía del estar cuya carencia de sistema explícito no implica ausencia de método, de camino: "Porque la vida, como la duración es heterogénea, móvil. En este sentido no tiene ella un sentido trazado, que pueda seguir metódicamente. Sino que vida y camino son una y la misma cosa, y crear la vida es crear camino." 5

El núcleo mediático a través del cual se expresará y sobre el que se irá desarrollando dicha filosofía, sea en el ensayo como forma de pensamiento, sean las notas de viaje, los epígrafes y comentarios como apuntes que dejan entrever el fluir de la conciencia en la ejecución del pensar, o sea la poesía como la acción que ampara y revela la interioridad, es el sentido de la presencia: presencia y sentido. ¿Y qué acusa este sentido, sino una constelación ${ }^{6}$ que convoca por medio de sí tantos como la razón se atreva a acariciar? Imaginar diestro para

${ }^{4}$ Arturo García Hernández, "Ramón Xirau, miembro numerario de la Academia Mexicana de la Lengua", en La Jornada, 26 de octubre de 1994, México, Sec. Cultura, s/p.

${ }^{5}$ Ramón Xirau, Duración y existencia. Tesis que presenta para obtener el grado de doctor en filosofía, 1947, México, UNAM-Facultad de Filosofía y Letras, p. 48.

${ }^{6}$ El término de constelación lo retomo de Ramón Xirau, Tres poetas de la soledad, 1955 , México, Antigua Librería Robredo, p. 24. 
hallar la presteza del conceptuar, del tiempo vivido en su revoloteo, contrapeso entre las luces de la ciudad:

Pero las luces de la ciudad especulan

Con el níquel de las ventanas

Y no hay vida que no tenga

Algún principio puro,

Ni nacimiento sin muerte,

Ni explosión sin espuma,

Ni negación total sin la presencia. ${ }^{7}$

Principio puro, que a pesar de tanto marasmo y desasosiego nunca hemos olvidado su signo y desde el cual Xirau legitima su interés por el acto insondable de estar, de aventurar y pervivir, de aspirar hacia lo que atrae y acecha, aquello que se cuida y se cela. Quizá después de tanto, la ceniza sea rastro que nos guíe hacia ese canturreo de la fuente que mana, y lo que aguarde, incluso para el apóstata, sea remanso para saciar la sed que alguna vez se creyó inagotable.

\section{Entre poesía y filosofía: coordenadas de una frontera}

Xirau comenta en clases, en conferencias, en reuniones: "hay que leer a Platón". Lector avezado de los Diálogos, provoca en los demás una lectura sostenida en demora, habrá que detenerse en las palabras, hacer girar la deliberación en el gesto mínimo o dilatarse en frases que llevarán al alma a descubrir el pretil que salvaguarda la sabiduría y el conocimiento.

Difícil olvidar de los Diálogos de Platón, el de La República o de lo justo, pues con el tiempo provocará el debatido desencuentro entre poesía y filosofía, lastimadura imborrable que terminará por enceguecer su propio origen. Queda, por un lado, sitiada la filosofía en su razón

\footnotetext{
${ }^{7}$ Ramón Xirau, "Presencia" (fragmento), en Poemes. Poemas, op. cit., p. 9.
} 
prístina y, por el otro, la poesía exiliada en su canto sibilino. ¿Qué hubiera sido de la ciudad sin tal expulsión?, ¿se habrían levantado tan altas murallas? ¿Y no es acaso una muralla, linde en defensa de un orden que prometía rebasar el serrallo de la impiedad? La división no implicaba ruptura de unidad, sino lisura, definición y pertenencia.

Sea la poesía hacia las sombras, sea la filosofía hacia el cielo. No podía ser de otra manera. El poeta doblemente proscrito es alejado de la ciudad por imitar un mundo que a su vez era remedo del mundo de las ideas y, desterrado de sí, para dar cabida en su inspirar a lo desdeñado por carecer de medida, a lo acaecido en delirio, al deseo y a la sospecha, a lo no todavía siendo, a lo que yace en anhelo de compasión y en soplo de fulgor.

Y el orden racional tiene que prescindir de esta mitad que es parte de cada uno de los hombres: la sombra y la oscuridad. El verdadero poeta, el que está en lo oscuro y vive en lo oscuro, tiene apenas cabida en un Estado racional. Su labor habrá de reducirse a cantar 'himnos a los dioses' y 'elogios a los hombres famosos'. [...] Platón, temeroso de las potencias oscuras, arrastrado en el Fedro por el poeta que llevaba dentro como un demonio o como un ángel, tuvo que renunciar a sí mismo, a lo que Jung llamaría 'la vertiente de la sombra' que todo hombre lleva en la conciencia. ${ }^{8}$

La poesía asume en la mayor humildad, hay que decirlo, el vivir al margen de una historia que se escribirá a través de su penumbra; consecuencia inevitable será el frágil equilibrio entre la libertad y el destino al confundir la razón las progresiones que la entraman; y en esta cesura, la legitimidad de la incordura iniciará su oriente en el alma. Quizá Platón, a sabiendas, prefirió alejar a la poesía de lo que habría de sobrevenir, pues creación de hombres y no de dioses, las ciudades regresarán inevitablemente al polvo del cual surgieron.

\footnotetext{
${ }^{8}$ Ramón Xirau, "Poesía y significado", en Entre la poesía y el conocimiento. Antología de ensayos críticos sobre poetas y poesía iberoamericanos, 2001, México, FCE, Col. Tierra Firme, p. 551.
} 
Entre la poesía y la filosofía, lo inmutable y lo transitorio, lo vivido y lo por vivir, la evocación y el olvido, tal vez el mirar lo que quiere es entender el despliegue del razonamiento en su interioridad, no otro que el de su latido: "Constatemos el hecho de este movimiento de sístole y diástole sin pronunciarnos acerca de su naturaleza íntima." ¿Qué decir en el altísimo murmullo del silencio? Quede atrás el titubeo, caídos en el nacer, todo ir naciendo es un ir ascendiendo: un velar la avidez que relampaguea en él dentro de las palabras y ampararse tras un firmamento que se desborda en miríada.
¿Y qué busco en las cosas, sino es tu huella llameante, tu herida luminosa en las hojas trémulas de los pájaros? ${ }^{10}$

Huella y herida, hojas trémulas que en el levante del vuelo son tan sólo trazos; acierto de ventura aunque quede sólo la seña, porque la ausencia no acusa pérdida sino hallazgo. Una vez mirado y hallado lo que no es posible mirar ni hallar en plenitud, los ojos en esa visión se iluminarán en faro y habrán así de adentrarnos en un auténtico estar que es presencia, ¿pero acaso no hablábamos de poesía?; ¿puede la poesía dar conocimiento?, de hacerlo ¿de qué clase de conocimiento hablamos?

Cuando empleo aquí la palabra conocimiento debe ser entendida como forma del saber y, especialmente, como forma de este saber que algunos, como Dilthey, llaman 'cosmovisión' o visión del mundo y que prefiero llamar, con un término viejo y rico: metafísica. Si el conocimiento remite a las cuestiones vitales que el hombre se plantea-nuestro origen, nuestro destino, el tiempo, la vida misma, la posible inmortalidad

${ }^{9}$ Ramón Xirau, El péndulo y la espiral, 1994, México, El Colegio Nacional, p. 12. Más adelante en p. 46 “[...] La decadencia de Occidente es, en muchas de sus páginas, un bello poema, un poema que viene a decirnos que nada nuevo existe bajo el sol [...] De izquierda a derecha, en un minuto, en sesenta años, en el curso de algunos siglos, el compás del péndulo empieza y acaba la vida de los insectos, los hombres y los pueblos."

${ }^{10}$ Ramón Xirau, "Presencia" (fragmento), op. cit., p. 9. 
y la posible divinidad- metafísica y poesía se aúnan. Tal vez-y solamente tal vez-con una sola diferencia: el poeta, por lo menos en su obra escrita no describe siempre su método aunque a veces (Lucrecio) pueda hacerlo mientras que el filósofo suele hacer el método más explícito. ${ }^{11}$

¿Si la poesía brinda serenidad para tanta pesadumbre, dónde la filosofía? Lo cierto es que si la poesía por sí misma hubiera sanado la dolencia que aqueja desde los antiguos, la filosofía no habría tenido cabida en el corazón del hombre. La filosofía es concebida en su transcurrir, en su destreza para analizar y discernir, lo cual implica conceptuar, polemizar, delimitar, acotar, hacer comunidad en la semejanza y en la diferencia para subsanar las tribulaciones que conforman nuestro vivir:

Pero acaso no sea inútil recordar que en sus orígenes helénicos la palabra filosofía no significaba ni técnica, ni erudición; significaba sabiduría vital, sabiduría de quien alcanza a entender cómo vivir esta vida. La filosofía más auténtica ha sido siempre aquella que se plantea problemas radicales: ¿qué somos?; ¿qué hacemos en esta vida?; ¿cuáles son nuestro origen y nuestro destino tanto histórico como transhistórico? ${ }^{12}$

En otro texto Xirau considera que:

La filosofía -como el Arte, como la Poesía-se dirige al saber. Existen naturalmente, caminos distintos para alcanzar el saber, pero el saber es unitario. La filosofía es tal vez este saber que busca, a veces vislumbra, algunas veces encuentra, lo universal en lo particular. ${ }^{13}$

¿Cómo hacer filosofía si no es por medio de una mayéutica que enarbole la discusión y la consumación de la palabra en el habla compartida? Con-vencer, práctica donde vencido y vencedor terminarán por asirse al suelo que será deslinde en medio del desánimo y

${ }^{11}$ Ramón Xirau, Poesía y conocimiento, 1978, México, Cuadernos Joaquín Mortiz, p. 12.

${ }^{12}$ Ramón Xirau, Ciudades, 1990, México, El Colegio Nacional, p. 43.

${ }^{13}$ Ramón Xirau, De ideas y no ideas, 1974, México, Joaquín Mortiz, p. 7. 
del desconcierto, y al final de la contienda serán la cara y la cruz de la razón cuando se aboca a resolver lo que le es más propio, el problema, valiéndose de un ejercicio que ha cultivado desde sus inicios, es decir, la argumentación.

Argumentar es aquí dar pruebas; pruebas que son muestra; muestras que provienen no necesariamente de mí mismo sino de lo que han dicho, siglo a siglo, poetas, artistas, hombres de religión y de religiones. Mis pruebas son también sus pruebas; pruebas de todos los hombres capaces de pasar por prueba y experiencia. ${ }^{14}$

Siguiendo a Xirau no habremos de confundir el quehacer filosófico con el poético, pues se tratan de dos sendas que van abriéndose paso en esta realidad única que al moverse persiste otorgando realidad a lo demás; como tampoco habremos de despreciar la fusión entre el concepto y la imagen, para lograr un entendimiento parcial de lo que todavía nos maravilla a pesar de nuestro desconsuelo y que nos confirma la alegría inherente al no tan simple hecho de vivir:

Suele pensarse, erróneamente, que el decir poético se distingue del decir filosófico en cuanto el primero es fundamentalmente imagen y el segundo es principalmente concepto. [...] El pensamiento filosófico es frecuentemente, y fundamentalmente a veces imaginativo; el conocimiento de los poetas puede ser conceptual; [...] Imagen y concepto están presentes tanto en la filosofía como en la poesía. ${ }^{15}$

Sea el pensamiento un diálogo interior de múltiples voces, ${ }^{16}$ sea su circular, la secreta lumbre de las palabras que al ser dichas son semilla de un vislumbrar, que por momentos se sospecha anterior a toda desgarradura, pero humanos y heridos habremos de contemplarnos en la fractura fundamental que da lugar a que la memoria profese

${ }^{14}$ Ibidem, p. 77.

${ }^{15}$ Ramón Xirau, Poesía y conocimiento, op. cit., p. 137.

${ }^{16}$ Platón, "Sofista o del Ser", en Diálogos, 1979, México, Porrúa, p. 780: "El diálogo interior del alma, el que tiene consigo misma, sin el auxilio de la voz, es lo que llamamos pensamiento." 
su habilidad especulativa; así las cosas para dar fe de sí, para erigir razones que sean solar: decir cielo para decir viento, lluvia, estrellas, y para que Xirau hable de la Presencia y su Sentido.

\section{Sentido de la presencia: entre el tiempo y la memoria}

Desde el Sentido de la presencia (1953), Xirau centra su inquietud alrededor del tiempo vivido y del estar para ofrecer una alternativa a la crisis propiciada por la deificación de lo relativo. Indudable es la zozobra como síntoma de nuestros días, ulular que encubre una dolencia de naturaleza desconocida que merodea por los vericuetos de la mente hasta imbuirla en la esfera de la incongruencia y del absurdo, negruras que ni los juicios más lacerantes han sabido vencer. He ahí la caída del auriga, el concepto de la angustia, la risa de los falsos ídolos, el vacío enaltecido en la persecución de la nada, vértice del estupor y mueca del terror.

Se vive en crisis y Xirau sigue su ondular rítmico de forma insistente en el desarrollo de su obra; menciono algunos títulos: Duración y existencia (1947); Sentido de la presencia (1953); El péndulo y la espiral (1959); Palabra y silencio (1968); De ideas y no ideas (1974); El tiempo vivido (1985). A continuación dos citas que aclaran este rubro, de El desarrollo y las crisis de la filosofía occidental (1975):

Lo que llamamos crisis consiste en tomar la parte por el todo y absolutizar la parte como si la parte fuera de hecho el todo. Deificar la parte -llámese placer, llámese intelecto, llámese Progreso o Historia o llámese Hombre cuando el hombre intenta, a veces sin saberlo, a convertirse en su propio dios acaba por convertirse en su propio ídolo. [...] y así destruir la posible armonía que, dentro de su límite y finitud, los hombres pueden alcanzar y parecen a veces haber alcanzado. Ni emoción pura ni pura razón, sino recuperación de la emoción reflexiva, de la reflexión emotiva. ${ }^{17}$

${ }^{17}$ Ramón Xirau, El desarrollo y las crisis de la filosofia occidental, 1975, España, Alianza, p. 8-9. 
De Dos poetas y lo sagrado (1980):

La esencia de lo que llamo crisis consiste en considerar que una parte de la realidad pueda convertirse y deba ser vista como la totalidad de lo real. En otras palabras, toda crisis, una vez que se ha perdido a Dios, conduce a la adoración de falsos dioses ahora absolutizados. ${ }^{18}$

La crisis de nuestro tiempo, el debate entre la razón y la emoción, son indicios que permiten replantear a Xirau la necesidad de un pensamiento que construya zonas de seguridad que salven del aturdimiento. ¿Si el pensamiento no ha de brindar consuelo, entonces, para qué pensar? Y si de pensar se trata, habrá que mencionar que el pensamiento habita donde la palabra se profiere desde la hondura de quien busca sentirse y declararse: umbral inmemorial del laberinto que es conocerse a sí mismo.

¿Será el sentido de la presencia, en su mesura y en el acierto de su viveza, una mostración del dintel a cruzar; un resguardo en este trance donde la desolación es la moneda en uso; una respuesta a una contrariedad extrema? ¿Y qué entender bajo el término de sentido de la presencia sino un centro cuyo vaticinio acusa una experiencia originaria? Pero poco habremos de entender si no atendemos que bajo su propuesta el análisis del tiempo es una arista nodal:

Afirmar el presente, y únicamente el presente, es tratar de acogerse al instante, el momento, lo fugaz y ya pasado cuando está sucediendo. Aparte del presente, existe la presencia, el estar vivo en esta nuestra vida donde somos, acaso, como lo pensó Platón y lo pensó sobre todo San Agustín, imagen móvil de la eternidad. En este sentido, la presencia no tiene nada fugaz; es permanencia, es plenitud. ${ }^{19}$

En lo descrito por Xirau sobre la concepción del tiempo en San Agustín destaca la observación de que si el pasado ya no es y el futu-

${ }^{18}$ Ramón Xirau, Dos poetas y lo sagrado, 1980, México, Cuadernos de Joaquín Mortiz, p. 14 y 17.

${ }^{19}$ Ramón Xirau, ¿Más allá del nihilismo?, 1991, México, El Colegio Nacional, p. 67-8. 
ro todavía no es, el presente es un paso entre dos tiempos que ya no existen; la negación de la temporalidad es la negación de la estancia. La cuestión será considerar la posibilidad de tal negación como rúbrica de la dificultad a estimar, pues porta consigo la creencia de que se vive en el paso fugitivo y efímero del instante; y bajo lo imperdurable, la única certeza es que poco o nada podría vivirse, es decir, sin un tiempo como estancia, la vida no podría sobrevenir. Explica el autor:

Cuando decimos que el pasado es memoria estamos diciendo que estamos en el tiempo y que este tiempo está en nuestro cuerpo y en nuestra alma. Estar, es decir, no vivir el tiempo como si fuéramos un vehículo puramente móvil sino vivirlo ahora, en nuestro estar, en nuestra presencia. [Y en nota a pie de página]: 'El 'estar', en esta vida terrestre, es o puede ser un verdadero 'morar' que no excluye sino que reclama un estar más alto." ${ }^{20}$

Lo inequívoco es que estamos en el tiempo, vivir es estar, el estar es una duración en marcha; ${ }^{21}$ somos tiempo en tanto que estamos con los otros, y lo Otro, en presencia: atalaya que se vislumbra en los significados que articulan la vida y hondonada que en ocasiones tiembla y que siempre es cifra que se dona. Xirau constantemente refiere lo que comprende bajo estos temas, y en este deambular, el lector es testigo de cómo ensaya su capacidad discursiva para elaborar conceptos que buscan definir lo que habita en ellos:

Estar: palabra que nos permite expresar este tiempo vivo que verdaderamente nos constituye, esta distensión en que realmente estamos. [...] este tiempo memorioso, atento, previsor -el tiempo en que estamos-,

${ }^{20}$ Ramón Xirau, Ars Brevis. Epigrafes y comentarios, 1985, México, El Colegio Nacional, p. 50.

${ }^{21}$ Ramón Xirau, El tiempo vivido. Acerca del estar, op. cit., p. 88: "En efecto, estar es 'duración estable', en el constante movimiento que, centrado en la atención, va y camina y se bifurca en pasados, futuros, futuros-pasados, memorias-previsión. Hay que decirlo con Heráclito, quien lo decía del fuego: el hombre 'cambiando reposa', en permanencia de cuerpo y alma, de 'alma-cuerpo'." 
es el tiempo de nuestra interioridad, de nuestra intimidad, de nuestra conciencia contemplativa [...]. Presencia: porque no es en el presente fugaz y medible que vivimos, cuando realmente estamos, sino constante presencia a lo largo de toda nuestra vida, situada siempre en la estancia, en la presencia. 22

Entre el estar y la temporalidad: el tiempo verdadero, el tiempo interno que hila el morar, acción que en su actuarse genera un sentimiento de pertenencia, que nos aleja del extravío resultante de creer que el olvido es remedio para el naufragio. Pareciera difícil estar en el tiempo o temporalizar el estar, pero al estarse en el tiempo se es presencia y se está en presencia. ¿Presencia es tiempo interno y certeza de vida auténtica? Xirau evoca constantemente el verso de Guillén: "Soy, más, estoy. Respiro" 23 y distingue la perspectiva de que la presencia sea tiempo vivo, tiempo vivido, tiempo memorioso, que como bien dice San Agustín es reflejo de la imagen móvil de la eternidad.

El enlace entre tiempo vivido-memoria-presencia, percibido en el núcleo mediático del sentido de la presencia, porta consigo la herencia heracliteana de un río-fuego que cambiando reposa, símbolo del logos que ha de pronunciarse de muchas maneras y entre ellas presencia, tiempo de adentro, filigrana inscrita en la memoria; puntualiza Xirau: "Pensar es recordar y, cercanos a Bergson, también hay que decirlo, sin la memoria, sin lo que la duración dura y perdura, no habría presencia. [...] la memoria forma parte de nuestra estancia y nos la hace posible." ${ }^{24}$ Se perpetúa lo vivido porque la memoria es flexión, y su facultad de especulación entendida como arte y creación rompe

${ }^{22}$ Ramón Xirau, El desarrollo y las crisis de la filosofía occidental, op. cit., p. 199.

${ }^{23}$ Jorge Guillén, "Más allá I”, en Cántico. Desnudo. Antología poética, 1988, Madrid, Biblioteca El Mundo y Revista Unidad Editorial, S. A., Páginas Amarillas, p. 5.

${ }^{24}$ Ramón Xirau, El tiempo vivido. Acerca de 'Estar', op. cit., p. 65. El tema viene desde Duración y existencia, op. cit. p. 20: "No hay posibilidad de durar sin recordar; y tanto más profunda es mi duración, cuanto más hondo sea el nivel de memoria en el que me encuentre. La alcurnia agustiniana de esta distinción entre el tiempo externo y la tensión temporal interna nos parece evidente. [...] Un ser sin memoria no puede entenderse.” Más adelante en p. 21: "el tiempo no se ve sino que se es". 
la cadencia imperceptible del tiempo cuantitativo para arrojarnos a un presente profundo: una presencia para sernos en el tiempo, por estar y haber tiempo, y de la que Xirau habrá de dar cuenta.

\section{La experiencia del tremor}

Queda ante lo inefable la claridad de haberlo vivido, si bien quedamos en silencio, cierto es que su elocuencia nos llevará a insertarnos en la cadencia del existir. Apalabrar, estar en el tiempo a través de las palabras, porque el lenguaje es también mundo; sea en el decir o en el escribir, en el argumentar o en el guarecer su anchura, apalabramos para encontrar una verdad que nos permitirá asumirnos como un yosujeto frente a lo indecible, a lo Otro. En las palabras, dentro, abajo, arriba, sea en su murmullo, en su acentuarse, en su caligrafía, incluso en su omisión es donde se nos entrega el estar y se asiste a la vida en su incesante marcha, en la urdimbre de su persistencia y su fugacidad; en el sigilo de la muerte rozando el anverso de los labios; en la dolorosa seducción de la nostalgia como primera seña del hambre de eternidad. Apalabrar, en el sosiego de una conversación donde a veces quedamos perplejos, donde el balbuceo es el primer trino, y donde el desconcierto en su arcano, nos acerca al presentimiento de la huella que confiesa la huida de la presencia.

Pensar sobre un sentido que se desdibuja a la par que se traza, gesto cuyo exceso rebasa la univocidad conceptual, y quedamos así ante las sombras proyectadas en la pared de la caverna, perfilando oscuridades, y mordiendo reclamos que tarde o temprano llevarán a arriesgarse hacia el sol. ¿Quién quiere ser enceguecido? ¿Cómo templar la mirada? ¿Cómo explicar la pluralidad de la creación? ¿Cómo no perder la cordura? Desposeído de todo, el filósofo se atreve a mirar el sol, y se le llenan de luz los ojos. Detención, el aliento se pausa ante lo que aprisiona y hace tremar.

Conquistado el poeta por la penumbra y deslumbrado el filósofo por el albor, parece que el periplo hacia el sentido de la presencia 
es el reverberar de un espejo cuyos bordes remiten a sí mismos. No obstante, la discusión se acota en el imperativo de su experienciarse, lo que confirma el haber experiencia como primer grado del saber, ${ }^{25}$ y como bien advierte Xirau:

Hay que salir de este mundo, hay que escalar las paredes de la caverna, hay que salir de ella, hay que dejarse deslumbrar por el sol para después mirarlo con los ojos abiertos. Pero también hay que regresar a esta tierra para decirles a los hombres que el lugar donde viven es de sombra y que deben llegar a la luz. ${ }^{26}$

¿Cómo relatar tal experiencia; o el sólo decirla provoca el vivirla? ¿Se trata de definir o de mostrar aquello que bien dice San Juan de la Cruz sólo se 'cura con la presencia y figura'? Xirau refiriéndose a San Juan expone: "Las imágenes, más que espejos, son, así, ventanas. Esta transmisión de una experiencia indecible, exige necesariamente, la ruptura del lenguaje en el centro mismo de sus significaciones." 27 Sea la ruptura del lenguaje en su entraña el derrotero para compartir una experiencia que resguarda un referente intraducible, inmaculado, que sobrecoge hasta el enmudecer y que abre la plurivocidad de la significación por medio de la esfera de la sugerencia; relación y suspensión entre la palabra y el silencio que se apuntala en la llamada 'palabra viva':

Joan Maragall, a quien debemos leer muy atentamente, cuenta cómo en los Pirineos, se encontró con una niña que tenía 'voz de hada'. El poeta señaló hacia el cielo y le preguntó a la niña: ‘qqué es esto?' La niña le contestó, 'lis esteles', y Maragall comentaba: 'yo supe que eso también

${ }^{25}$ Aristóteles, “Libro I. Cap I”, en Metafísica, 1980, México, Porrúa, p. 5 "En los hombres la experiencia proviene de la memoria. En efecto muchos recuerdos de una misma cosa constituyen una experiencia. [...] Por la experiencia, progresan la ciencia y el arte en el hombre."

${ }^{26}$ Ramón Xirau, El tiempo vivido. Acerca del estar, op. cit., p. 90.

${ }^{27}$ Ramón Xirau, "El madero ardiente", en Palabra y silencio, 1985, México, Siglo XXI, p. 51. 
era hablar'. Así el gran poeta sería el que alcanzara a decir, simple y llanamente, 'este pino es verde', 'el mar es azul' o 'azulísimo'. ${ }^{28}$

Así, cuando se le pregunta a Xirau qué es el sentido de la presencia, contesta con precisión a través de la creación de una imagen: 'la presencia es ir dentro del barco', ${ }^{29}$ lo cual remite a la interpretación que realiza del poema Le bateau ivre de Rimbaud: "El barco simboliza al hombre mismo y la aventura del barco es la aventura del hombre." 30 Años después en su Discurso de ingreso a la Academia Mexicana (1995) retoma la frase: "la presencia que es navegación hacia lo real eterno." ¿'Será que el cielo que mira desde su barco rebrilla de estrellas como palabras vivas?

Finalmente una cita del ensayo "De la presencia" (1999) que tiene como antecedente el verso de Guillén referido, y que es ejemplo de cómo la idea rectora se ha cargado de un significado superior al congregar en torno a sí los puntos comentados; asimismo ejemplo de cómo logra un discurrir que al decantarse en su proceso, se afina en su formulación, hasta conseguir una simplicidad que da testimonio sobre lo que en un principio fue el preámbulo de un temblor:

Es este estar en el mundo el que nos permite precisamente respirar, es decir, vivir. No es otro el sentido de la presencia. En efecto, ya lo veía San Agustín en el libro XI de las Confesiones: el pasado, el futuro, el presente, no existen y si vemos que somos tiempo y el tiempo no existe, tampoco nosotros existimos. Pero nuestro tiempo, el de nuestra vida verdadera es el de la presencia. Tiempo continuadamente nuestro, en nuestra estancia en el mundo, la presencia es constantemente un ahora, atento al mundo, a los demás, atento al Otro, a los dioses, a la divinidad. Baste ahora un ejemplo que puede ser una ayuda sin acabar de ser una

${ }^{28}$ Ramón Xirau, "Letras. Artes. Crítica", en Ars Brevis. Epígrafes y comentarios, 1990, México, El Colegio Nacional, p. 99-100.

${ }^{29}$ Mariana Bernárdez, "Entrevista con Ramón Xirau: la presencia es ir dentro del barco", en Periódico de poesía, Nueva Época, n 5, Primavera 1994, INBA-UnAM, México, p. 53.

${ }^{30}$ Ramón Xirau, Sentido de la presencia, op. cit., p. 30.

${ }^{31}$ Ramón Xirau, De la presencia, 1995, México, El Colegio Nacional, p. 31. 
explicación. Imaginemos un barco; si lo vemos pasar desde fuera el barco es pura movilidad pero, si lo vivimos navegadamente desde dentro, el barco es continuidad y es presencia. ${ }^{32}$

A algunos causa extrañeza que el nudo de tal filosofía del estar sea desatado recurriendo a una argumentación plena de imágenes, que se enriquecen y relacionan a lo largo del desarrollo de la escritura. Sin embargo, Xirau demuestra con ello que es permisible compartir la experiencia radical del sentido de la presencia, al llevar el lenguaje común hacia sus extremos para tocar el dentro de lo impronunciable; arriesga en este periplo la emergencia de un pensamiento imaginativo, un pensamiento vivo resultante del cruce entre el poder evocativo de la imagen y la exactitud diamantina del concepto en su discernimiento; como él mismo explica: "Habría que añadir que en la imagen persiste el pensamiento y que en pensamiento e imagen persisten los misterios." ¿33 ¿Por qué un filósofo enamora las orillas del misterio y la poesía? ¿Qué avista en el lance de la tensión exacerbada? ¿La relación íntima entre estas dos orillas como formas de un conocer más amplio: el conocer religioso, que nos lleva a hacer común lo inscrito en el desierto? ¿Un confín?

Si límite es lo que intuye Xirau será el del horizonte del círculo, cerco formado alrededor del rostro inapresable de lo sagrado: prosentia y religatio. Estamos sujetos al mundo, y se descubra o no la noche oscura, habremos de contar lo vivido desde la insuficiencia que paradójicamente da cabida a la desmesura. La condición a cumplir será la de aceptar que la reconstrucción de lo visto comportará una larga travesía: habrá que enumerar las arenas, los bordes de las dunas, repasar

32 Ramón Xirau, Cinco filósofos y lo sagrado, y un ensayo sobre la presencia, 1999, México, El Colegio Nacional, p. 118.

${ }^{33}$ Ramón Xirau, "Saludo a Alejandro Rossi", en Saludos y homenajes. Palabras para miembros de El Colegio Nacional, 1999, México, El Colegio Nacional, p. 75. También en "Letras. Artes. Crítica", en Ars Brevis. Epígrafes y comentarios, op. cit., p. 99: "la más alta poesía es la que se lleva a cabo por medio de la imagen. Entiendo por imagen aquella manera y aquel modo poético que remite de manera directa, 'sin dar vueltas' (tal es el sentido de 'tropo') al objeto dicho por el poeta." 
incesantemente lo dicho y lo no dicho; para que en esta titilación se logre que del círculo se desprenda una línea, y de la línea un gesto que selle la alianza entre el camino y el método, ruta que será transitada una y otra vez, y en ese vaivén, ensayar, flexionar, re-flexionar, susurrar, des/arrobarse hasta hallar la voz: viento antiguo del mundo ${ }^{34}$ que enrame lo visto, aunque sólo sea posible la alusión a $\operatorname{algo} o^{35}$ que no es un sentido último, sino una mediación entre una palabra brutalmente finita y una visión incompleta de ese algo.

\section{A ras de luz}

Entre los ojos y lo visto se ha pretendido que: "Sólo para ver sirven los ojos, solamente para ver, se ha creído -se sigue creyendo-. Y así los ojos que no lloran se confunden." 36 ¿Terminará su con/fusión cuando recuerden las aguas de los ríos navegados? Mirar en el latido para contemplar, y templarse en la con/moción y en el con/moverse. Mucho habrá de andarse hasta apresar esa limpidez. "¿Quién llama a los dioses?, ¿quién los busca? El filósofo, sin duda; también el poeta. El poeta no arguye, no argumenta. Ve, puesto que la poesía es esencialmente mirar, ver, percibir. El filósofo trata de argüir y argumentar."37 Mientras el filósofo argumenta, el poeta vela y devela al corazón en su percusión. Sin embargo, ambos partirán de la fascinación inducida por lo insondable y ambos llegarán a formular, en distintos tonos, un mismo ruego:

El Otro, ¿dónde el Otro?

No lo dicen las palabras, no

${ }^{34}$ Ramón Xirau, “Canto VII. El Cordero”, en Poemes. Poemas, op. cit., p. 79.

${ }^{35}$ Retomo el término en el contexto descrito magistralmente por María Zambrano, El hombre y lo divino, 1991, Madrid, Siruela, p. 33: "Pero todo atestigua que la vida humana ha sentido siempre estar ante algo, bajo algo, más bien."

${ }^{36}$ María Zambrano, El hombre y lo divino, op. cit., p. 363.

${ }^{37}$ Ramón Xirau, "María Zambrano: en torno a lo divino", en Cinco filósofos y lo sagrado, op. cit., p. 105. 
lo cantan las palabras.

Y sin embargo ellas lo dicen,

el Otro que nos busca, y nos quiere y nos ve, ¿dónde, dolor de luz, dónde, luzduelo? ${ }^{38}$

En el ámbito de la pregunta es permisible postular una verdad para la comprensión y la bondad, ya que la importancia de la pregunta no radica en la respuesta que siempre la anida, sino en ese desasimiento que transparenta lo que se custodia, y el lugar de ese calado es explorado por Xirau, ¿una tercera vía?, ¿un pensamiento que va más allá de ser imaginativo, pues la brillantez de la especulación requiere del espacio de la expresión poética para adentrarse en la espesura? ¿Un pensar que en vuelo rasga lo impenetrable? La sola enunciación de su emergencia hace mella en la dureza del discurso, y mella debe hacerse pues lo que se busca es aligerar la carga del corazón para que aletee en la fuerza de su ritmo, que ello también es pensar.

¿Será capaz este tipo de pensamiento de elaborar juicios que penetren el dominio de los enigmas? ¿Quién querrá medir y pesar la música de las esferas después de saber que quien usurpa el lugar de la Esfinge, condenado está a no ser dios ni hombre? Y la mudez irrumpe cuando el preguntar es un mecanismo inútil que no brinda sustento ni certeza alguna; entonces, el silencio deviene ahuecando el respiro, en silbido corta el aire y por un instante aquieta el correr del mundo, una fisura en el tiempo para capturar y despertar con su habla, los signos que poco habrán de entenderse y sí mucho soñarse. Bienaventuranza.

Lenguaje de palabra, lenguaje de silencio, lenguas de fuego, lenguas de viento para entronarnos en la visitación de la ausencia que acusa el destello, difícil pues comenzar desde lo no presente para llegar a lo presente, pero el lenguaje porta consigo el poderío de la invocación que hará retornar lo ido, ya sea valiéndose de la analogía como anagnórisis, la paradoja como tensión de los contrarios, la imagen como fusión

${ }^{38}$ Ramón Xirau, "Del mismo y del Otro" (Fragmento), en Poemes. Poemas, op. cit., p. 43. 
entre lo distinto y lo distante. Encuentro-tensión-fusión, confluyen para ser fundamento de la metáfora, danzas que lograrán la cesación del sentido para descubrir uno mayor: volver a hacer presencia en el corazón, ¿y quién pudiera quedarse ahí en ese aire tan transparente, en esa sublime esfera del contemplar? Una tregua, que muchos han sido los días enumerando arenas y queda tras del recuento, un poco de polvo en la mano, reiteración de que sólo perdiéndonos es posible encontrarnos, gozo que nos vuelve al compás primario que irrumpe en el respirar y el latir.

¿Donación? ¿Revelación? ¿Y cómo habremos de lograr tal altozano, o acaso la luz irradia en desigual y análoga manera? Es tal la manifestación de la presencia que la palabra calificada para resguardarnos frente a este fondo último nacerá en prenda; por un lado, condicionará el ocultamiento a cambio de una fidelidad inquebrantable; por otro, su generosidad se derramará para ser abrazo y arraigo, pues la palabra se consuma en quien la canta, y al en-cantarla, nos declaramos en y con el Mundo. Vivir es estar en las palabras, ${ }^{39}$ y entre el vivir y el estar, se atestigua el infinito misterio que nos guarece para hacernos partícipes:

El misterio nos admira, nos asombra y nos conduce no tanto al temor como al 'pasmo'. Naturalmente el misterio queda en el reino de lo indefinible. Gabriel Marcel observaba que la diferencia entre un problema y un misterio reside en que el problema admite siempre una solución; el misterio se entrega pero es indemostrable. ${ }^{40}$

Sea lo indemostrable la frontera que esculpe los contornos de nuestra humanidad y sea recinto que marque este haber querido ser como

${ }^{39}$ Ramón Xirau, Octavio Paz: el sentido de la palabra, 1970, México, Serie del Volador, Joaquín Mortiz, p. 25 y 87. "Se trata del sentido de la vida. Para entender este sentido hay que entender su significado. La vida misma nos remite a las palabras y las palabras dan el significado y el sentido de la vida. Vivir es estar en las palabras, en los signos, en las significaciones: realidad y ausencia de realidad; mejor: realidad más allá de lo que solemos llamar real o ausente."

${ }^{40}$ Ramón Xirau, Dos poetas y lo sagrado, op. cit., p. 17. 
dioses ${ }^{41}$ por portar, inexplicablemente, el recuerdo de la completitud y por sabernos rostro de su Rostro. ¿Acaso sea al final del día este apalabrar, este lenguaje surcando milenios, la prueba más fehaciente de toda la finitud que nos habita?, ¿de qué otra forma podríamos explicar la inmensidad dentro de una sílaba?

Frágil la sílaba desterrándose de la totalidad, para liarse hacia otra y otra, hasta volverse espacio que nos vincula porque estamos en presencia; palabra que al oscilar da cuenta de la distancia inaugurada con su sola pronunciación y al hacerlo, salva el coto de lo profano para de nuevo insertarnos en su entraña. Lenguaje que estalla para confirmar nuestro aspirar, y como refiere Xirau en su ensayo sobre Wittgenstein: "lo indecible no es del todo indecible, porque podemos ponerlo de manifiesto de manera alusiva, aunque no lógica"; lo cual no implica que la expresión sea ilógica o a-lógica puesto que: "mostrar lo más alto consiste en sugerir lo que está en los límites o más allá de ellos". ${ }^{42}$ En el ánimo de lo indecible hay un ritmo que trina.

¿Y para qué entonar salmos tan delicados como el cristal? ¿Para tocar el quebranto que testifica una pertenencia y refrendar la revelación del silencio? ¿Para bautizar al mundo a pesar de haber perdido el rumbo hacia las aguas del Jordán? Cuánto liarse para seguir y no seguir siendo los mismos. Al fin hombres de polvo, sujetos a una corporalidad que sacramenta la vida en su vivirse y que nos encarna en la inescrutable cifra de ser alma y cuerpo, misterio que significa: "encarnación de todos para que más allá de esta dolorosa y amorosa estancia del mundo, se nos dé de verdad la presencia de hombres de carne y hueso que podrán morar, después de la muerte, en la verdadera

${ }^{41}$ Ramón Xirau, Sentido de la presencia, op. cit., p. 11-2, dice al respecto: "En el símbolo de la tentación está implícito el elemento esencial del problema del ser. En las palabras de la serpiente la continua metáfora del hombre, su continuo intento de integrarse y llegar a ser como Dios. 'Seréis como Dios', dice la serpiente. Y entonces el hombre come el fruto, trata de integrar en su carne el conocimiento mismo de la divinidad, trata de ser este conocimiento y de ser la divinidad que le da sustancia. Pero al tratar de ser Dios el hombre ya trata de ser lo que no es."

${ }^{42}$ Ramón Xirau, Cuatro filósofos y lo sagrado, op. cit., p. 72-3. 
carne y los verdaderos huesos de la Morada, el espíritu encarnado en la Morada." $" 43$

Sea la palabra encarnada aquella que se dona en la gracia del verbo entrañado, luminosidad que nos requiere y nos nombra. ¿Podremos proclamar, y a la vez, sostener ese filo de Misterio? ¿Acaso alguna vez custodiemos el instante de albor en el Huerto de los Olivos? Xirau dirá con Paz 'translumbramiento', ${ }^{44}$ alumbrarse para que el aliento arriesgue su vuelo tras el resplandor de la pura presencia amorosa, y entender sin entender, que la cima y el fondo son la raíz de un reconocer incalculable: sentir la caricia y recordar el fluir del río en la piel, sea entonces el sentido de la presencia, la presencia y el sentido.

${ }^{43}$ Ramón Xirau, El tiempo vivido. Acerca del estar, op. cit., p. 90.

${ }^{44}$ Ramón Xirau, Octavio Paz: el sentido de la palabra, op. cit., p. 98. "Desde el mundo de las apariencias subimos - 'peregrinación hacia las claridades'- al 'translumbramiento', a la fuente de luz donde todo es -como lo era el fuego exterior a la caverna platónica- unidad sin sombra." La 'estrofa' del poema 'Blanco' de Paz dice: "Translumbramiento: / no pienso, veo / -no lo que veo, / los reflejos, los pensamientos veo." 
CITAM Derechos Reservados.

La reproducción total o parcial de este artículo se podrá hacer si el ITAM otorga la autorización previamente por escrito. 